\title{
Hypoxia-induced accumulation of erythropoietin mRNA in isolated hepatocytes is inhibited by protein kinase $\mathrm{C}$
}

\author{
Kai-Uwe Eckardt ${ }^{1}$, Albert Ring ${ }^{1}$, Manfred Maier ${ }^{1}$, Bernhard Gess ${ }^{1}$, Doriano Fabbro ${ }^{2}$, Armin Kurtz ${ }^{1}$ \\ ${ }^{1}$ Institute of Physiology, University of Regensburg, Universitätsstrasse 31, D-93053 Regensburg, Germany \\ ${ }^{2}$ Ciba Geigy, CH-Basel, Switzerland
}

Received July 5, 1993/Received after revision and accepted September 10, 1993

\begin{abstract}
To define the role of protein kinase C (PKC) in oxygen-dependent production of erythropoietin (EPO) in the liver, we have determined EPO messenger ribonucleic acid (mRNA) expression in primary cultures of juvenile rat hepatocytes incubated at different oxygen tensions in the absence and presence of phorbol esters, vasopressin, and structurally different kinase inhibitors. Upon reduction of oxygen concentrations from $40 \%$ to $3 \%$ EPO mRNA in cultured hepatocytes increased markedly within $1.25 \mathrm{~h}$, reached maximal values after $2.5 \mathrm{~h}$ and remained elevated for up to $72 \mathrm{~h}$. Treatment of hepatocytes during $1.25-5 \mathrm{~h}$ of hypoxic exposure with phorbol 12-myristate-13 acetate (PMA) attenuated hypoxiainduced EPO mRNA levels dose-dependently by a maximum of approximately $50 \%$. This inhibitory effect of PMA disappeared upon treatment for more than $5 \mathrm{~h}$ and was completely lost after incubation for 9 and $18 \mathrm{~h}$ in the presence of $10^{-6} \mathrm{M}$ and $10^{-7} \mathrm{M}$ PMA, respectively. Phorbol 12,13-dibutyrate and vasopressin also inhibited EPO mRNA accumulation, whereas 4 alpha-phorbol 12,13-didecanoate was ineffective. Western blot analysis of PKC isozymes revealed the presence of PKC alpha, beta II, delta, epsilon and zeta and provided no evidence that the PMA-induced inhibition of EPO expression was associated with depletion of any of these isozymes. Conversely, PMA-induced inhibition of EPO mRNA accumulation was paralleled by translocation of PKC alpha from cytosol to membranes and the time- and dose-dependent attenuation of the inhibitory effect of PMA on EPO mRNA levels was paralleled by down-regulation of PKC alpha. A dose-dependent inhibition of EPO mRNA formation, independent of effects on total RNA synthesis, as determined by $\left[{ }^{3} \mathrm{H}\right]$ uridine incorporation, was also found in the presence of the kinase inhibitor staurosporine $\left(\mathrm{ED}_{50} \sim 2 \times 10^{-8} \mathrm{M}\right)$ and three structurally related derivatives with increased selectivity for PKC (RO 317549, $\mathrm{ED}_{50} \sim 1 \times 10^{-6} \mathrm{M}$; RO 318220, $\mathrm{ED}_{50} \sim 1 \times$
\end{abstract}

Correspondence to: K.-U. Eckardt, Department of Nephrologie, Universitätsklinikum Rudolf Virchow, Spandauer Damm 130, D14050 Berlin, Germany
$10^{-6} \mathrm{M}$ and CGP $41251, \mathrm{ED}_{50} \sim 4 \times 10^{-6} \mathrm{M}$ ). The markedly lower potency of the latter three compounds as compared to staurosporine suggests that this suppression of EPO gene induction was not mediated by inhibition of PKC. In summary the data indicate that PKC alpha is a negative modulator of EPO gene expression in hepatocytes. A kinase other than PKC, however, appears to be an essential element of hypoxic signalling.

Key words: Erythropoietin - Hepatocytes - Hypoxia - Protein kinase $\mathrm{C}$ - Gene expression

\section{Introduction}

Erythropoietin (EPO), the major humoral regulator of erythropoiesis, is produced by the liver and kidneys in an inverse relation to oxygen availability [30]. The major control of oxygen-dependent EPO formation has been shown to operate at the level of its messenger ribonucleic acid (mRNA) [3, 4, 43]. Increases in EPO mRNA levels upon hypoxia are at least in part mediated by increased transcription of the EPO gene [44]. The cellular mechanisms through which changes in oxygen availability determine EPO gene expression are in spite of several hypotheses [30] largely unknown, as in other cases of oxygen-dependent gene control [17].

Recent evidence indicates that phospholipid and calcium-dependent protein kinase (PKC) may play an important role in hypoxic signalling in a variety of systems. PKC consists of at least eight isozymes, several of which are coexpressed in single cells and unequally distributed between cytosol and membranes [1, 37, 48]. In general, activation of $\mathrm{PKC}$ is associated with increased membrane binding of the enzyme and a parallel decrease in cytosolic activity. Prolonged membrane association may initiate proteolytic degradation or "down-regulation", a process which affects different PKC isozymes to a different extent and at different rates [1, 37, 48]. It was 
therefore taken as evidence for a possible role of PKC as mediator of hypoxic signal transduction, when a translocation of PKC from cytosol to membranes and a reduction of its activity was observed in fetal rat brain during anoxia [34], and in renal LLCPK1 cells upon hypoxic incubation in vitro [42]. Moreover, hypoxia-mediated impaired differentiation of LLCPK1 cells [41] was mimicked upon treatment of normoxic cells with phorbol esters [42], known activators of PKC [1, 37, 48]. In pulmonary artery smooth muscle cells, hypoxia is known to induce contraction and proliferation. The sustained phase of hypoxia-induced contraction was found to be inhibited in the presence of an inhibitor of PKC and activation of PKC was found to be a prerequisite for pulmonary artery smooth muscle cells to proliferate in response to hypoxic exposure in vitro [10].

In view of these findings it appears of interest that recent evidence also suggests that $\mathrm{PKC}$ may be involved in the regulation of oxygen-dependent EPO formation. However, since it has so far not been possible to isolate the cells physiologically producing EPO in liver and kidneys, these studies have been confined to EPO-producing tumour cell lines, and the results obtained with these cell lines are inconclusive and have led to controversial interpretations. Thus, using the human hepatoma cell lines Hep G2 and Hep 3B, which produce EPO in an oxygen-dependent fashion [22] and a renal carcinoma cell line, which secretes EPO constitutively [24], several investigators reported that phorbol esters reduce EPO formation [19, 25, 31, 33]. However, in addition, inhibitors of PKC were found to diminish EPO secretion by Hep G2 cells [31, 33]. Moreover, one group found that the reduction of EPO formation upon treatment with phorbol esters in Hep G2 cells is due to depletion of PKC [31], whereas others did not obtain clear evidence that down-regulation of PKC is associated with the inhibition of EPO formation [33]. Finally, synthetic analogues of diacylglycerol, the endogenous activator of PKC $[1,37,48]$ were found to inhibit EPO secretion in renal carcinoma cells [25] and Hep 3B cells [19], but had no effect on EPO production in Hep G2 cells [33]. It is possible that these different results may be due to intrinsic properties of the different tumour cell lines under investigation, and overall it remains unclear whether activation of PKC inhibits EPO formation, or if conversely, down-regulation and inhibition of PKC reduces EPO production under certain conditions. Some investigators have, however, clearly favoured this latter possibility, suggesting that PKC plays an important permissive role in the stimulation of EPO production [31].

In the present investigation we aimed to clarify the role of PKC in EPO formation of cells that are physiological production sites of the hormone. Since in juvenile rats the liver is the predominant site of EPO formation [15], and since hepatocytes have recently been identified as the main cellular site of EPO production in the liver $[32,45]$ we have studied EPO production in primary cultures of juvenile rat hepatocytes. Recently we have shown that steady-state levels of EPO mRNA in isolated hepatocytes increase approximately 15 -fold after incubation at reduced oxygen tensions for $18 \mathrm{~h}$
[16]. This indicates that primary cultures of hepatocytes can be used to investigate oxygen-dependent control of EPO formation in vitro. To define the role of PKC in hepatic EPO formation, hepatocytes isolated from juvenile rats were incubated in the present study at varying oxygen tensions in the absence and presence of phorbol esters, of vasopressin, a known activator of PKC in hepatocytes [28] and of seven potential, structurally different, inhibitors of PKC. Effects on EPO mRNA levels were related to changes in total RNA synthesis and compared with changes in the abundance and distribution of different isozymes of PKC.

\section{Materials and methods}

Animals. Male Sprague Dawley rats age 10-20 days, bred in the local animal house were used.

Liver cell isolation. Cells were isolated from livers using a twostage in situ perfusion via the portal vein [2] in a non-recirculating system. The basic perfusion medium consisted of Hanks buffered salt solution (HBSS: $137 \mathrm{mM} \mathrm{NaCl}, 3.7 \mathrm{mM} \mathrm{KCl}, 0.4 \mathrm{mM}$ $\mathrm{KH}_{2} \mathrm{PO}_{4}, 0.3 \mathrm{mM} \mathrm{Na} \mathrm{HPO}_{4}, 4 \mathrm{mM} \mathrm{NaHCO}, 5.5 \mathrm{mM}$ glucose) and was supplemented with $10 \mathrm{mM}$ 4(2-hydroxyethyl)-1-piperazineethane sulphonic acid (HEPES), $0.5 \mathrm{mM}$ ethyleneglycolbis(aminoethylether)tetraacetate (EGTA) (medium 1) or with 10 $\mathrm{mM}$ HEPES, $5 \mathrm{mM} \mathrm{CaCl}, 0.1 \mathrm{mg} / \mathrm{ml}$ collagenase $(0.287 \mathrm{U} / \mathrm{mg})$ (medium 2). After cannulation of the portal vein, livers were flushed with $1 \mathrm{ml}$ sodium heparin $(1000 \mathrm{U} / \mathrm{ml})$, then perfused with medium 1 for $5 \mathrm{~min}$ at a rate of $4.5 \mathrm{ml} / \mathrm{min}$ and subsequently with medium 2 for $8 \mathrm{~min}$ at a rate of $3.8 \mathrm{ml} / \mathrm{min}$. Perfusion media were preoxygenated and prewarmed to $37^{\circ} \mathrm{C}$. After excision livers were immediately placed in ice-cold HBSS and cells were gently liberated into the buffer after opening of the liver capsule. The suspension was cleared of the connective tissue framework and remaining clumps of tissue by filtration through a $50 \mu \mathrm{m}$ nylon sieve.

Cell culture. Hepatocytes were preferentially sedimented by centrifugation at $80 \mathrm{~g}$ for $3 \mathrm{~min}$ and washed thrice in ice-cold HBSS. Cell viability as assessed by the trypan blue exclusion criterion was always greater than $85 \%$. Cells were suspended in minimal essential medium, supplemented with $10 \%$ fetal bovine serum, glutamine $(2 \mathrm{mM})$, penicillin $(50 \mathrm{U} / \mathrm{ml})$, streptomycin sulphate $(50 \mu \mathrm{g} / \mathrm{ml})$, insulin $(10 \mu \mathrm{g} / \mathrm{ml})$ and hydrocortisone $(2 \mu \mathrm{g} / \mathrm{ml})$ and were routinely plated at a density of $8-11 \times 10^{4}$ cells $/ \mathrm{cm}^{2}$ in 175 $\mathrm{cm}^{2}$ dishes. After $4 \mathrm{~h}$ incubation at $40 \% \mathrm{O}_{2} / 5 \% \mathrm{CO}_{2} / 55 \% \mathrm{~N}_{2}$, to allow cell attachment, the culture medium was removed together with the majority of non-attached cells, the percentage of which was consistently less than $10 \%$, and cultures were refed the same medium without serum supplementation. For studies of the time course of changes in EPO mRNA levels subsequent incubation was carried out for $1.25-72 \mathrm{~h}$ at $3 \%$ or $40 \% \mathrm{O}_{2} / 5 \% \mathrm{CO}_{2} /$ balance $\mathrm{N}_{2}$ in waterjacketed incubators (Model 3319 and 3336, Forma Scientific, Marietta, Ohio, USA). Cells isolated from two animals were generally combined and yielded 12-16 dishes, from which at least 1 dish of cells without treatment was kept at $3 \% \mathrm{O}_{2}$ or $40 \% \mathrm{O}_{2}$ to provide internal controls. For pharmacological studies cells were generally incubated for $1.25-18 \mathrm{~h}$. Stock solutions of pharmacological agents were prepared in dimethylsulphoxide (DMSO) and added to the serum-free medium after the preincubation phase (final concentration of DMSO $0.1 \%$ ).

In order to test the effect of pharmacological agents on the stability of EPO mRNA, hepatocytes were incubated at $3 \% \mathrm{O}_{2}$ for $2.5 \mathrm{~h}$ in the absence of drugs to induce accumulation of EPO mRNA and thereafter exposed to $40 \% \mathrm{O}_{2}$ for $1.25 \mathrm{~h}$ in the presence of agents.

Measurement of EPO $m R N A$. Cells were harvested with trypsin ethylenediaminetetraacetate (EDTA), snap frozen in liquid nitro- 
gen and stored at $-70^{\circ} \mathrm{C}$ prior to RNA extraction. RNA was prepared using an acid/guanidinium thiocyanate/phenol/chloroform. extraction method [8] and was assayed by RNAse protection as described [38]. RNA probes were continuously labelled with [ $\alpha$ ${ }^{32}$ PJGTP $\left(1.5 \times 10^{13} \mathrm{~Bq} / \mathrm{mmol}\right)$ by SP6 polymerase, using a genomic rat EPO deoxyribonucleic acid (DNA) template, which comprised a Pst I-Sac I fragment, containing $132 \mathrm{bp}$ of exon $\mathrm{V}$ and approximately $300 \mathrm{bp}$ of the adjoining intron. $100-150 \mu \mathrm{g}$ total RNA was hybridized with 0.25 to $0.5 \times 10^{6} \mathrm{cpm}$ [ $(4.17-$ $8.34) \times 10^{3} \mathrm{~Bq}$ radiolabelled EPO probe in $80 \%$ formamide, 40 $\mathrm{mM}$ 1,4-piperazine-diethanesulphonic acid (PIPES, pH 6.4), 400 $\mathrm{mM} \mathrm{NaCl}, 1 \mathrm{mM}$ EDTA at $60^{\circ} \mathrm{C}$ overnight and RNAse digestion was performed at $20^{\circ} \mathrm{C}$ for $30 \mathrm{~min}$. Protected fragments were subjected to denaturing polyacrylamide gel electrophoresis (PAGE) and quantified by measuring radioactivity of excised portions of the dried gel in liquid scintillant (1500 Tri-Carb liquid Scintillation Analyzer, Packard Instrument Company, Downers Grove, IIl., USA). Equivalent amounts of yeast transfer RNA (tRNA) were run in each assay to assess background radioactivity. After background subtraction the radioactivity of each protected EPO mRNA fragment was divided by the quantity of total RNA analysed and expressed relative to an external standard, as described [15] consisting of $1 \mu \mathrm{g}$ pooled RNA extracted from kidneys of severly anaemic adult rats, which was coanalysed with each gel and assigned an arbitrary value of 1 .

Measurement of total RNA synthesis. $\left[{ }^{3} \mathrm{H}\right]$ Uridine incorporation into trichloroaceticacid (TCA)-insoluble material was used as a measure of total RNA synthesis as described [50] in cultures that were incubated under conditions identical to those used for measurement of EPO mRNA, except that $9.6-\mathrm{cm}^{2}$ dishes were used. In brief, $3.7 \times 10^{3} \mathrm{~Bq}\left[5^{3} \mathrm{H}\right]$ uridine $\left(1.04 \times 10^{12} \mathrm{~Bq}\right.$ mmol) was added to the dishes for $2.5 \mathrm{~h}$ of incubation at $3 \%$ or $40 \%$ oxygen. At the end of the incubation period the culture dishes were immediately transferred to a cold room. The cells were rinsed with $1 \mathrm{ml}$ ice-cold PBS, and the cell layers were covered with $3 \mathrm{ml}$ icecold TCA $(10 \%)$ to extract TCA-soluble nucleotides in situ at $4^{\circ} \mathrm{C}$ for $50 \mathrm{~min}$. After washing the cells three times with cold TCA $(10 \%)$, they were dried at room temperature and digested in $1 \mathrm{ml}$ of $1 \mathrm{~N} \mathrm{KOH}$. Radioactivity was counted in liquid scintillant after neutralization with $1 \mathrm{~N}$ HCL.

Immunodetection of PKC isozymes. Cytosolic and membrane fractions were prepared from hepatocytes incubated in the absence or presence of PMA $\left(10^{-8}-10^{-6} \mathrm{M}\right)$ for 2.5 or $18 \mathrm{~h}$ at $3 \%$ or $40 \%$ oxygen. At the end of incubation culture dishes were placed on ice, cells were washed thrice with TBS $\left(4^{\circ} \mathrm{C}\right)$, supplemented with leupeptin $(10 \mu \mathrm{g} / \mathrm{ml})$ and aprotinin $(2 \mu \mathrm{g} / \mathrm{ml})$, and scraped into $1 \mathrm{ml}$ of sonication buffer ( $20 \mathrm{mM}$ TRIS-HCl, $2 \mathrm{mM}$ EGTA, $2 \mathrm{mM}$ EDTA, $6 \mathrm{mM}$ beta-mercaptoethanol, $2 \mu \mathrm{g} / \mathrm{ml}$ aprotinin and $10 \mu \mathrm{g} /$ $\mathrm{ml}$ leupeptin). Cell suspensions were sonicated ( 3 bursts of $75 \mathrm{~W}$ ) and extracts were spun at $100,000 \mathrm{~g}$ for $1 \mathrm{~h}$, yielding the cytosolic supernatant. Pellets were resuspended in sonication buffer supplemented with $1 \%$ NP 40 and spun again at $100,000 \mathrm{~g}$ for $1 \mathrm{~h}$ to yield the membrane fraction.

Protein concentration in cytosolic and membrane fractions was determined by the Bradford method [6] and samples of $300 \mu \mathrm{g}$ protein were subjected to SDS-PAGE and thereafter transferred onto nitrocellulose filters. After being washed, filters were incubated with a monoclonal antibody against the alpha isozyme, or polyclonal antibodies against the beta I, beta II, gamma, delta, epsilon, zeta and eta isozymes of PKC exactly as described [5]. Binding was detected by autoradiography after incubation with ${ }^{125}$ I-labelled antibodies against mouse gamma-globulin and autoradiograms were evaluated by laser densitometry (elscript 400 , Hirschmann, Unterhaching, Germany).

Statistics. Student's paired $t$-test was used for comparison of EPO mRNA levels in pharmacologically treated hepatocytes with those in control dishes obtained from the same cell preparation, which were incubated and analysed in parallel; $P<0.05$ was considered significant.
Agents. Phorbol 12-myristate (PMA), phorbol 12,13 dibutyrate (PDBu), 4- $\alpha$-phorbol 12,13 didecanoate ( $\alpha$-PDD), protease inhibitors, staurosporine, dioctanoylglycerol (DOG) and oleoyl-acetylglycerol (OAG) and vasopressin were from Sigma. NP 40 was from Calbiochem, collagenase was from Boehringer Mannheim, cell culture medium and fetal bovine serum were from Gibco BRL. Radiochemicals were purchased from Amersham. A monoclonal antibody against PKC alpha was from Amersham, a polyclonal antibody against PKC gamma from Seikagaku Kogyo (Tokyo, Japan). Polyclonal antibodies against PKC beta I and beta II were generous gifts from Dr. S. Jaken (Lake Placid, NY, USA) and polyclonal antibodies against other PKC isozymes were prepared as described [29]. 1-(5-Isoquinolinesulphonyl)-2-methylpiperazine (H 7), $N$-[2-(methylamino)ethyl]-5-isoquinoline-sulphonamide $(\mathrm{H}$ 8) and $N$-(2-aminoethyl)-5-isoquinolinesulphonamide (H 9) were from Research Biochemicals. RO 31 8220, RO 317549 and CGP 41251 were gifts from Roche Products Limited, UK, and Ciba Geigy, Switzerland, respectively. A partial rat EPO DNA probe was kindly provided by Dr. P. J. Ratcliffe, Oxford, UK.

\section{Results}

\section{EPO mRNA levels in isolated hepatocytes incubated at different oxygen tensions}

Figure 1 shows the time course of EPO mRNA levels in primary cultures of hepatocytes. Although cells were isolated from normoxic animals EPO mRNA was readily detectable after cell isolation, which is in accordance with previous data from in vivo studies [15]. When cells were preincubated at $20 \%$ oxygen for $4 \mathrm{~h}$, as in previous experiments [16] average concentrations of EPO mRNA did not change significantly (not shown), but when preincubation of cells was performed at $40 \%$ oxygen, EPO mRNA levels after $4 \mathrm{~h}$ were significantly lower than immediately after isolation, and in many experiments became undetectable. Reducing the oxygen tension in the incubator to $3 \%$ after the end of the preincubation period resulted in a marked increase of EPO mRNA levels within $2.5 \mathrm{~h}$. Despite continued hypoxic exposure, a reduction of EPO mRNA levels occurred between 5 and $9 \mathrm{~h}$, before the concentration of EPO mRNA remained fairly constant. At $40 \%$ oxygen EPO mRNA levels remained low and a marked difference between incubation at $40 \%$ and $3 \%$ oxygen persisted during the period investigated.

For subsequent pharmacological studies hepatocytes were always preincubated for $4 \mathrm{~h}$ at $40 \%$ oxygen and thereafter exposed to $3 \%$ or $40 \%$ oxygen in the absence or presence of agents.

\section{Effect of phorbol esters on EPO mRNA accumulation and total RNA synthesis}

The effect of phorbol esters on EPO mRNA accumulation in rat hepatocytes incubated at 3\% oxygen for $1.25-18 \mathrm{~h}$ is shown in Fig. 2; Fig. $2 \mathrm{~A}$ is the autoradiogram of an RNAse protection assay from a single experiment with PMA, and Fig. 2 B, C illustrates the quantitative analysis, derived from the determination of the radioactivity of protected fragments in 4-10 independent 


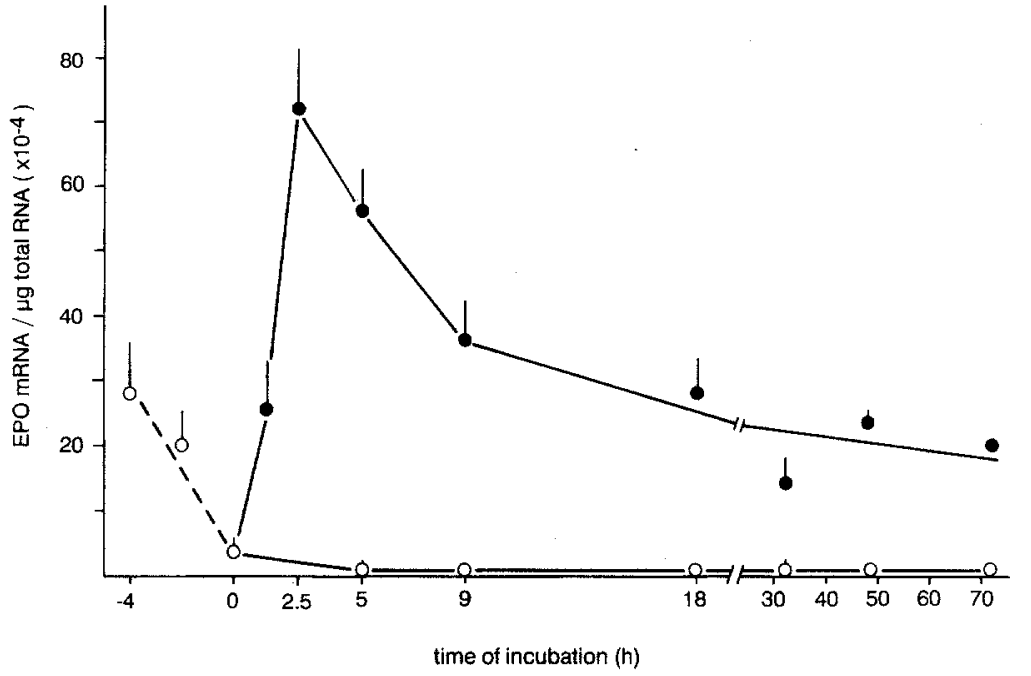

Fig. 1. Time course of erythropoietin messenger ribonucleic acid (EPO mRNA) levels in isolated rat hepatocytes. After isolation cells were preincubated for $4 \mathrm{~h}$ $(-4$ to $0 \mathrm{~h})$ at $40 \% \mathrm{O}_{2}$ in medium supplemented with $10 \%$ fetal calf serum (FCS) to allow cell attachment and thereafter incubated in serum-free medium at $40 \% \mathrm{O}_{2}$ (O) or $3 \% \mathrm{O}_{2}(\mathrm{O})$ for up to $72 \mathrm{~h}$. EPO mRNA was measured by RNAse protection using a ${ }^{32} \mathrm{P}$-labelled RNA probe and quantified by determination of the radioactivity of protected fragments. Values are expressed relative to an external standard (aliquot of pooled renal RNA) that was coanalysed on each gel and assigned an arbitrary value of 1 (mean $\pm \operatorname{SEM}, n=12$ )

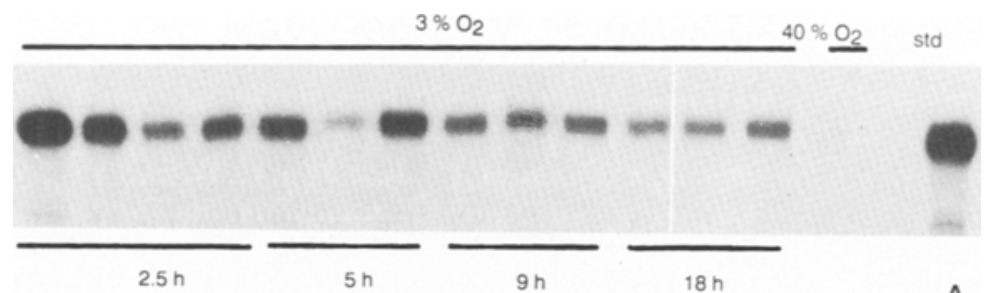

PMA

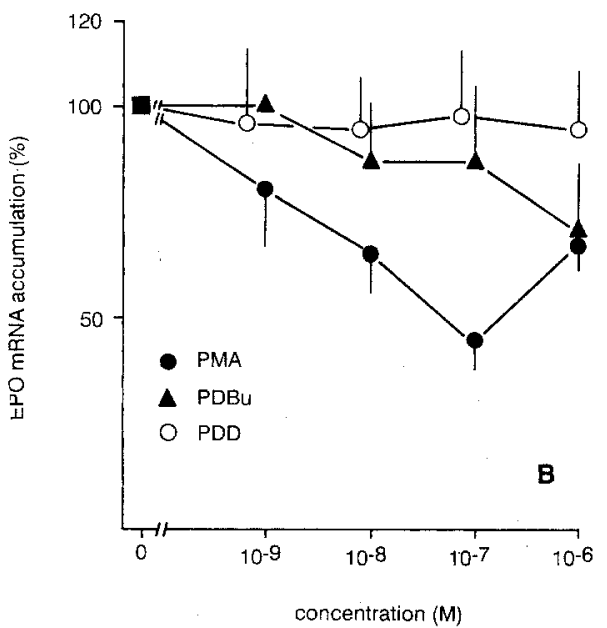

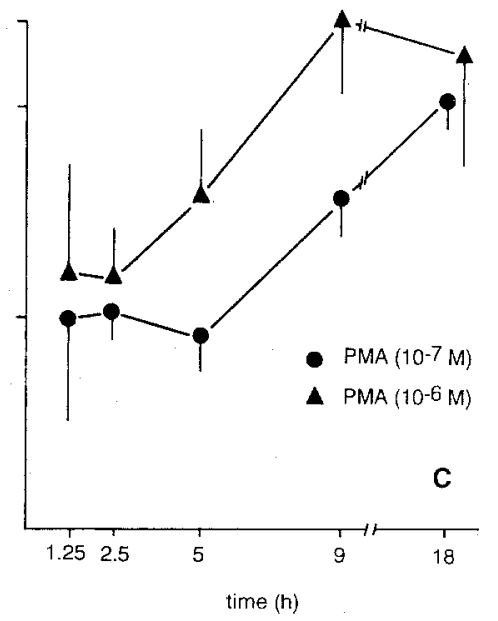

Fig. 2 A-C. Effect of phorbol esters on EPO mRNA accumulation in isolated hepatocytes incubated at $3 \% \mathrm{O}_{2}$ for $1.25-18 \mathrm{~h}$. A The autoradiograph of an RNAse protection assay of a single experiment with phorbol 12-myristate-13 acetate (PMA), using $110 \mu \mathrm{g}$ of total RNA from cells under each condition. B, C Quantitative analysis, derived from measurement of the radioactivity of protected fragments in RNAse protection assays of independent experiments in which cells were treated with different concentrations of PMA, phorbol 12,13 dibutyrate (PDBu) and $4 \alpha$-phorbol 12,13 didecanoate (PDD) for $2.5 \mathrm{~h}$ (B) or with two different concentrations of PMA for $1.25-18 \mathrm{~h}(\mathrm{C})$. Values are related to controls incubated in parallel at $3 \% \mathrm{O}_{2}$ in the absence of phorbol esters and are given as mean \pm SEM, $n=4-5$ except values for $10^{-6} \mathrm{M}$ and $10^{-7} \mathrm{M}$ PMA in (B) $(n=10)$. EPO mRNA values were significantly lower than in control dishes following treatment for $2.5 \mathrm{~h}$ with $10^{-8}, 10^{-7}$ or $10^{-6} \mathrm{M}$ PMA and $10^{-6} \mathrm{M}$ PDBu and also following treatment with $10^{-7} \mathrm{M}$ PMA for 1.25 or $9 \mathrm{~h}$ experiments with PMA, PDBu and alpha PDD. Treatment with PMA did not affect the yield of total RNA extractable from hepatocytes (not shown), but resulted in a dose- and time-dependent reduction of the level of EPO mRNA per $\mu g$ total RNA. Upon incubation for $2.5 \mathrm{~h}$ in the presence of PMA, reduction of EPO mRNA levels was maximal with $10^{-7} \mathrm{M}$ PMA (on average $56 \%$ ) and was less pronounced with a tenfold higher concentration (average reduction 33\%) (Fig. $2 \mathrm{~A}, \mathrm{~B}$ ). The reduction in EPO mRNA levels was already apparent after $1.25 \mathrm{~h}$ of incubation, but was reversed completely upon incubation in the presence of the phorbol ester for more than $2.5 \mathrm{~h}$. This loss of efficacy occured more rapidly with $10^{-6} \mathrm{M}$ PMA than with $10^{-7} \mathrm{M}$ PMA.
Thus average EPO mRNA levels in cells treated with $10^{-7}$ M PMA remained at about $50 \%$ of control values after $5 \mathrm{~h}$ and were still significantly reduced after $9 \mathrm{~h}$, whereas EPO mRNA concentrations after this time period were even slightly higher than in control cultures upon treatment with a tenfold higher dose (Fig. 2 C).

$\mathrm{PDBu}$ mimicked the effect of PMA, although with less potency, while the biologically inactive phorbol ester alpha PDD [47] did not affect EPO mRNA concentrations (Fig. 2 B). Phorbol esters did not increase EPO mRNA concentrations in hepatocytes incubated at $40 \%$ oxygen for $2.5 \mathrm{~h}$ (not shown).

In agreement with previous results [16] total RNA synthesis in hepatocytes, as determined by $\left[{ }^{3} \mathrm{H}\right]$ uridine 
Table 1. Effect of phorbol 12-myristate-13 acetate (PMA) and vasopressin on total RNA synthesis

\begin{tabular}{lll}
\hline Experimental condition & $\begin{array}{l}{\left[{ }^{3} \mathrm{H}\right] \text { Uridine }} \\
\text { trichloroacetic acid } \\
\text { (TCA)-insoluble } \\
\text { counts } \\
\text { (cpm per dish) }\end{array}$ \\
\hline $40 \% \mathrm{O}_{2}$ & Control & $2099 \pm 58$ \\
$3 \% \mathrm{O}_{2}$ & Control & $960 \pm 19$ \\
$3 \% \mathrm{O}_{2}$ & PMA $\left(10^{-8} \mathrm{M}\right)$ & $957 \pm 73$ \\
$3 \% \mathrm{O}_{2}$ & PMA $\left(10^{-7} \mathrm{M}\right)$ & $861 \pm 45$ \\
$3 \% \mathrm{O}_{2}$ & PMA $\left(10^{-6} \mathrm{M}\right)$ & $924 \pm 33$ \\
$3 \% \mathrm{O}_{2}$ & Vasopressin $\left(10^{-7} \mathrm{M}\right)$ & $933 \pm 52$ \\
\hline
\end{tabular}

Values are mean \pm SEM, $n=3-5$. Following $4 \mathrm{~h}$ preincubation at $40 \% \mathrm{O}_{2}$ cells were incubated for $2.5 \mathrm{~h}$ in the presence of agents and $3.7 \times 10^{3} \mathrm{~Bq}\left[{ }^{3} \mathrm{H}\right]$ uridine per dish

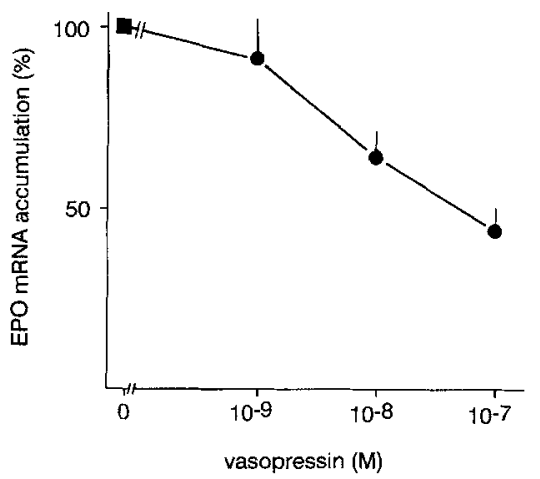

Fig. 3. Effect of vasopressin on EPO mRNA levels in isolated hepatocytes incubated at $3 \% \mathrm{O}_{2}$ for $2.5 \mathrm{~h}$. Values are related to controls incubated in parallel at $3 \% \mathrm{O}_{2}$ in the absence of vasopres$\sin$ (mean $\pm \mathrm{SEM}, n=3$ ). With $10^{-8}$ and $10^{-7} \mathrm{M}$ vasopressin EPO mRNA levels were significantly lower than in controls

incorporation, was approximately $50 \%$ lower at $3 \%$ oxygen as compared to $40 \%$ oxygen (Table 1 ). The inhibitory effect of phorbol esters on EPO mRNA accumulation was specific in so far as total RNA synthesis in the presence of PMA was unchanged or only slightly affected (Table 1).

\section{Effect of vasopressin and synthetic diacylglycerols on EPO mRNA accumulation}

In order to stimulate PKC through activation of phospholipase $\mathrm{C}$ hepatocytes were incubated for $2.5 \mathrm{~h}$ at $3 \%$ oxygen in the presence of vasopressin. As shown in Fig. 3, vasopressin reduced EPO mRNA levels in a dose-dependent fashion, without affecting total RNA synthesis (Table 1). Treatment with OAG and DOG $\left(10^{-4}-10^{-7} \mathrm{M}\right)$ for $2.5 \mathrm{~h}$ had no consistent effect on either basal or hypoxia-induced EPO mRNA levels (not shown).

\section{Immunological quantitation of PKC isozymes}

To relate dose- and time-dependent changes in EPO mRNA accumulation in the presence of PMA to changes

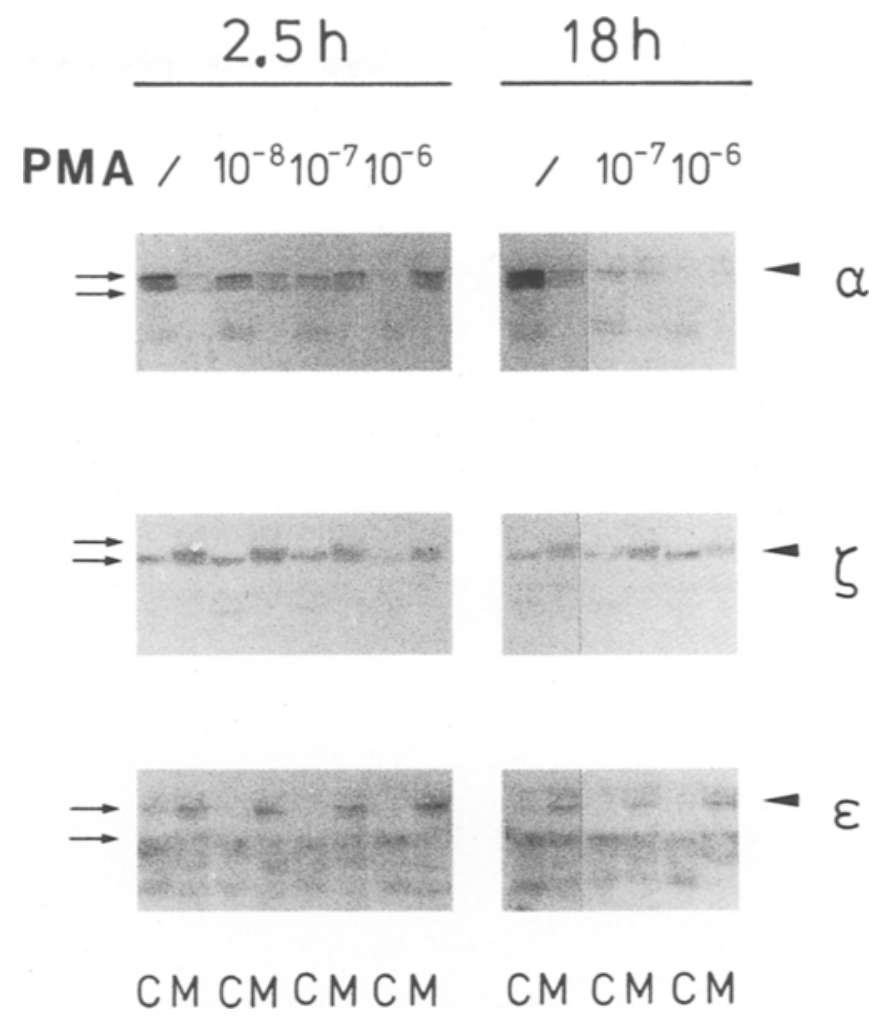

Fig. 4. Western blots of PKC alpha, zeta and epsilon, performed with cytosolic $(C)$ or membrane-bound $(M)$ protein of hepatocytes incubated at $3 \% \mathrm{O}_{2}$ for 2.5 or $18 \mathrm{~h}$ in the absence or presence of PMA. Arrows on the left correspond to molecular size markers (upper: $94 \mathrm{kDa}$, lower: $68 \mathrm{kDa}$ ). Autoradiograms are shown for one of three analyses with independent cell preparations, which provided similar results. For semiquantification autoradiograms were analysed by laser densitometry. Relative densitometric values for PKC alpha are given in Fig. 5. The slight increase in both the cytoplasmic and membrane bound PKC alpha band of untreated cells after $18 \mathrm{~h}$ as compared to $2.5 \mathrm{~h}$ on the illustrated autoradiogram was not reproducible in two other experiments. The immunoreactivity of PKC zeta showed no consistent change under PMA treatment. PKC epsilon in the cytosol decreased and in the membranes increased slightly under PMA treatment; when related to the signal in the membranes of untreated cells the intensities were: $0.75(C, 2.5 \mathrm{~h})$ and $0.25(C, 18 \mathrm{~h})$ in untreated cells and $0.22(C$, $2.5 \mathrm{~h}), 1.22(M, 2.5 \mathrm{~h}), 0.11(C, 18 \mathrm{~h})$ and $1.25(M, 18 \mathrm{~h})$ in cells treated with $10^{-6} \mathrm{M}$ PMA

in the subcellular distribution of PKC isozymes, cytosolic and membrane fractions were prepared from hepatocytes that were incubated at $3 \%$ or $40 \%$ oxygen for 2.5 or $18 \mathrm{~h}$ in parallel to cultures used for EPO mRNA measurements. Using Western blot analysis, PKC isozymes alpha, beta II, delta, epsilon and zeta, but not beta I, eta or gamma were detected in hepatocytes.

Neither in the absence nor presence of PMA was any consistent difference found in the abundance or subcellular distribution of PKC isozymes between cells incubated at 3 or $40 \%$ oxygen (not shown).

In the absence of PMA PKC alpha and beta II were predominantly found in the cytosolic fraction, while PKC delta, epsilon and zeta were predominantly membrane bound. Following treatment with PMA, no changes in the immunoreactivity of PKC beta II and zeta (Fig. 4) became apparent. In contrast, PKC $\alpha$ (Figs. 4, 


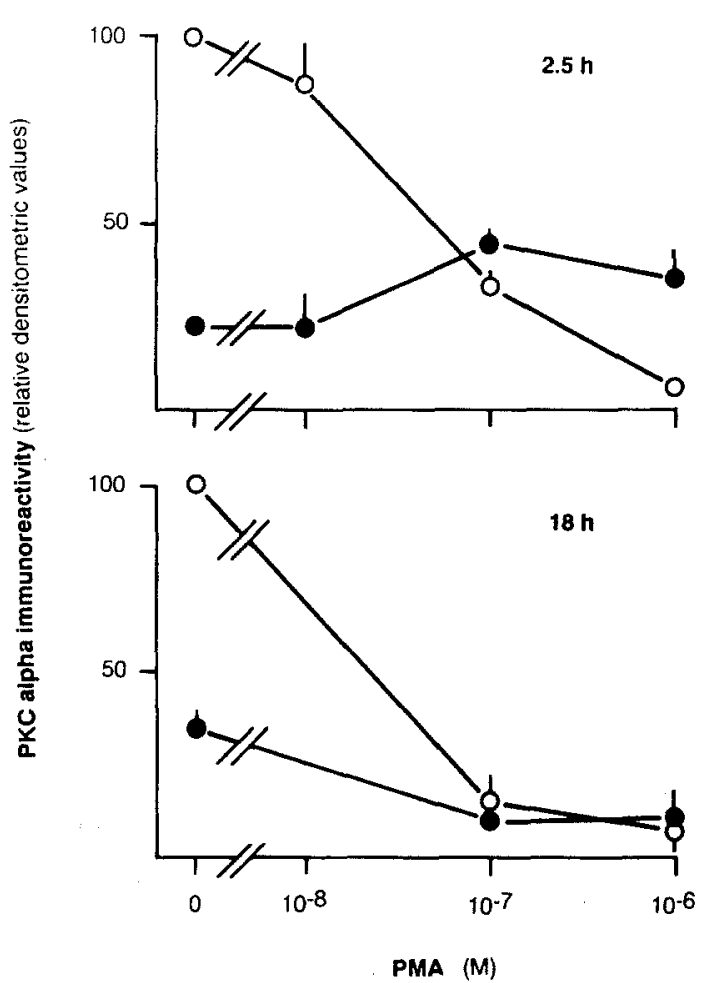

Fig. 5. Densitometric analysis of PKC alpha immunoreactivity in Western blots of three independent experiments performed with cytosolic $(O)$ or membrane-bound $(O)$ protein of hepatocytes incubated at $3 \% \mathrm{O}_{2}$ for 2.5 or $18 \mathrm{~h}$ in the absence or presence of PMA. Values are expressed as a percentage of the intensity in the membranes of untreated cells (mean \pm SEM)

5), epsilon (Fig. 4) and delta were translocated from cytosol to membranes, although at different concentrations of phorbol ester and to a different extent, which is in accordance with a previous study in rat hepatocytes [39]. As illustrated in the autoradiogram of a single experiment (Fig. 4) and by the densitometric analysis of three independent experiments (Fig. 5), translocation of PKC alpha and a commencing reduction of the overall abundance was found already after $2.5 \mathrm{~h}$ incubation with no less than $10^{-7} \mathrm{M}$ PMA. After $18 \mathrm{~h}$ incubation with no less than $10^{-7} \mathrm{M}$ PMA almost complete down-regulation had occurred (Figs. 4, 5). PKC $\varepsilon$ showed slight depletion of the cytosolic fraction with no less than $10^{-7}$ M PMA after both 2.5 and $18 \mathrm{~h}$, but no downregulation of the membrane-bound form (Fig. 4). A slight down-regulation of PKC delta was only seen at a concentration of PMA as high as $10^{-6} \mathrm{M}$ (not shown).

\section{Effects of kinase inhibitors on EPO $\mathrm{mRNA}$ levels and total RNA synthesis}

In an attempt to investigate hypoxia-induced EPO mRNA accumulation in the presence of reduced activity of PKC, cells exposed to $3 \%$ oxygen for $2.5 \mathrm{~h}$ were treated with staurosporine [40], the staurosporine derivatives CGP 41251 [35], RO 318220, RO 317549 [9, 12] and the isoquinolinesulphonamides $\mathrm{H} 7, \mathrm{H} 8$ and $\mathrm{H} 9$ [26]. In order to assess unspecific alterations of RNA syn- thesis, $\left[{ }^{3} \mathrm{H}\right]$ uridine incorporation was measured in parallel. As shown in Fig. 6, all kinase inhibitors tested led to a dose-dependent attenuation of EPO mRNA levels (closed symbols). Treatment with CGP 41251 reduced EPO mRNA levels $\left(\mathrm{ED}_{50} \sim 4 \times 10^{-6} \mathrm{M}\right.$ ) without having a significant effect on total RNA synthesis (open symbols) (Fig. 6 B). Treatment with the other kinase inhibitors affected not only EPO mRNA levels but also resulted in marked reduction of total RNA synthesis, albeit with lower potency in the case of staurosporine (Fig. $6 \mathrm{~A}$ ), RO 318220 and RO 317549 (Fig. 6 D) $\left(\mathrm{ED}_{50} \sim 2 \times 10^{-8} \mathrm{M}\right.$ vs $\sim 6 \times 10^{-7} \mathrm{M}, \sim 1 \times 10^{-6} \mathrm{M}$ vs $\sim 5 \times 10^{-6} \mathrm{M}$ and $\sim 1 \times 10^{-6} \mathrm{M}$ vs $\sim 6 \times 10^{-6} \mathrm{M}$ for inhibition of EPO mRNA accumulation and total RNA synthesis, respectively). $\mathrm{H} 7, \mathrm{H} 8$ and $\mathrm{H} 9$ inhibited EPO mRNA accumulation with about the same potency as total RNA synthesis (Fig. 6 C).

\section{Effect of PMA vasopressin and kinase inhibitors on the decay of EPO $m R N A$ after hypoxic stimulation of hepatocytes}

To assess indirectly if PMA and the kinase inhibitors reduce steady-state levels of EPO mRNA under hypoxia through inhibition of de novo synthesis of EPO mRNA or increased mRNA metabolism, hepatocytes were incubated at $3 \%$ oxygen in the absence of drugs to induce accumulation of EPO mRNA, and PMA $\left(10^{-7} \mathrm{M}\right)$, vasopressin $\left(10^{-7} \mathrm{M}\right)$, staurosporine $\left(10^{-8} \mathrm{M}\right)$, RO $318220\left(10^{-6} \mathrm{M}\right)$, RO $317549\left(10^{-6} \mathrm{M}\right)$ and CGP 41251 $\left(10^{-5} \mathrm{M}\right)$ were then added to cultures during a further incubation for $1.25 \mathrm{~h}$ at $40 \%$ oxygen. Figure 7 illustrates that EPO mRNA decreased by about two-thirds after $1.25 \mathrm{~h}$ and that this decay was not enhanced by any of the substances tested.

\section{Discussion}

Hepatocytes have recently been identified as the predominant site of oxygen-dependent EPO production in rats during the early postnatal period $[15,32,45]$, and we have previously observed that the ability of hepatocytes to modulate EPO production in an oxygen-dependent fashion is maintained after isolation of the cells [16]. Extending these observations, studies of the time course of EPO mRNA levels in isolated hepatocytes (Fig. 1) show that oxygen-dependent differences in EPO mRNA can be found for at least $72 \mathrm{~h}$ of primary culture under serum-free conditions when cells are incubated at either low or high oxygen pressures. As in the liver in vivo [49] and in cultured human hepatoma cells [18], the increase in EPO mRNA levels of isolated hepatocytes upon continuously reduced oxygen supply is in part only transient (Fig. 1). Although in cultured hepatocytes maximal concentrations of EPO mRNA were reached somewhat earlier than following the onset of hypoxia in vivo [49], the decline in EPO mRNA of isolated cells after $2.5-5 \mathrm{~h}$ of incubation suggests that the down-regulation of EPO production in vivo is not pri- 


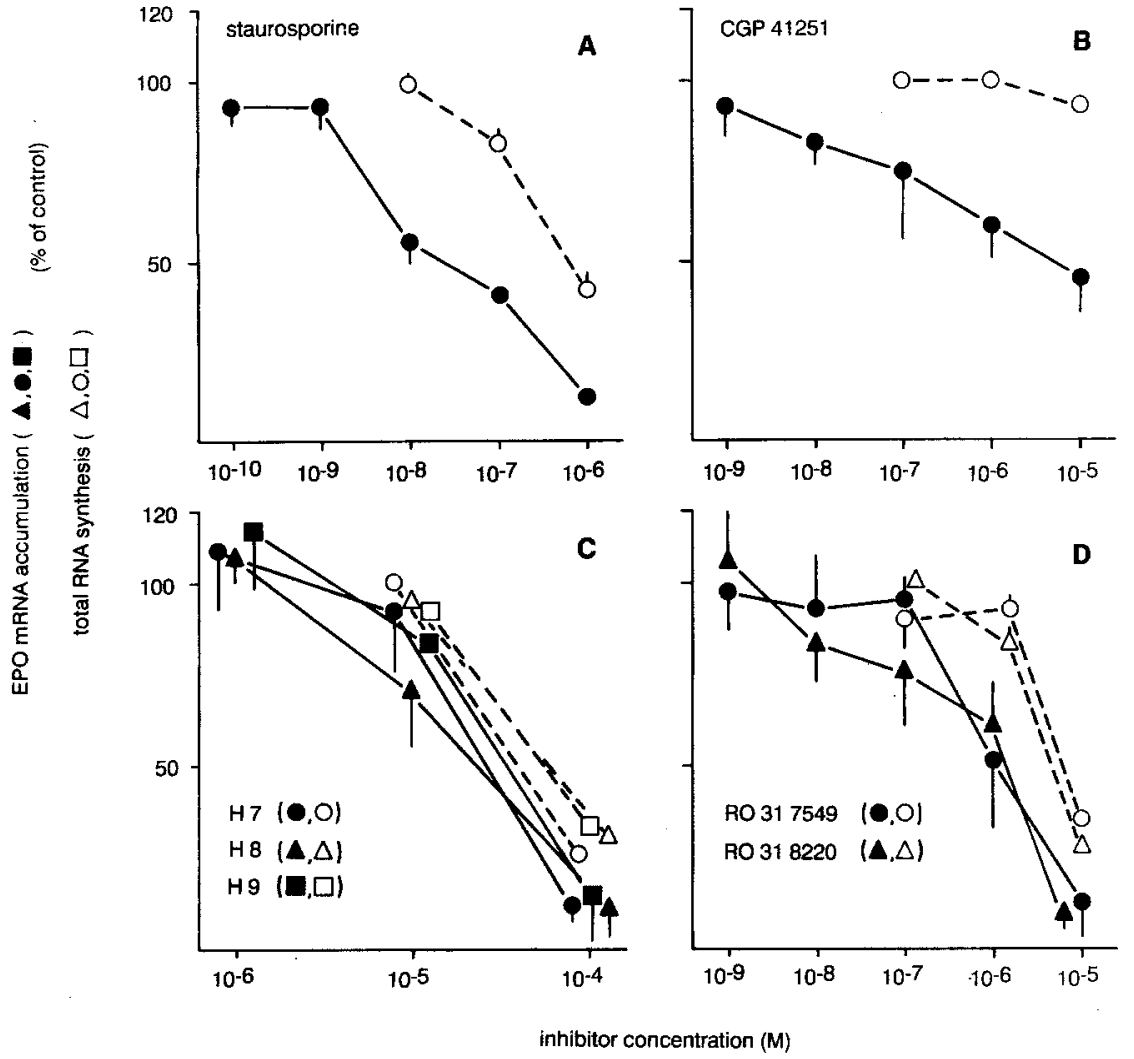

Fig. 6A-D. Effect of kinase inhibitors on EPO mRNA levels and total RNA synthesis in isolated hepatocytes incubated at 3\% oxygen for $2.5 \mathrm{~h}$. Values are related to controls from the same cell preparation, incubated in parallel at $3 \% \mathrm{O}_{2}$ in the absence of agents. EPO mRNA was quantified by RNAse protection and $\left[{ }^{3} \mathrm{H}\right]$ uridine incorporation into trichloroacetic-acid-(TCA)-insoluble material was used as a measure of total RNA synthesis. Values are mean \pm SEM, $n=5$. EPO mRNA levels were significantly lower than in controls following treatment with $\geqslant 10^{-8} \mathrm{M}$ staurosporine, $\geqslant 10^{-6} \mathrm{M}$ CGP $41251,10^{-4} \mathrm{M} \mathrm{H} 7, \mathrm{H} 8$ or $\mathrm{H} 9$ \{where $\mathrm{H} 7$ is 1-(5-isoquinolinesulphonyl)-2-methylpiperazine, $\mathrm{H} 8$ is $N$-[2-(methylamino)ethyl)5 -isoquinoline-sulphonamide and $\mathrm{H} 9$ is $\mathrm{N}$ (2-aminoethyl)-5-isoquinolinesulphonamide $\}$ and $\geq 10^{-6} \mathrm{M}$ RO 317549 or RO 318220 . Total RNA synthesis was significantly lower than in controls following treatment with $10^{-6} \mathrm{M}$ staurosporine, $10^{-4} \mathrm{M}$ $\mathrm{H} 7, \mathrm{H} 8$ or $\mathrm{H} 9,10^{-5} \mathrm{M}$ RO 317549 and $\geq 10^{-6} \mathrm{M}$ RO 318220 marily due to changes in peripheral oxygen availability [30], but rather depends on cellular mechanisms. With respect to further study of the oxygen dependent signal transduction that controls EPO formation, the kinetics of EPO mRNA levels in isolated hepatocytes indicate that short-term exposure of the cells to reduced oxygen tensions provides a suitable model system.

Using this system to test a role of PKC in hepatic EPO formation we found evidence for a significant effect of this kinase. Two active phorbol esters, PMA and $\mathrm{PDBu}$, and vasopressin, a physiological activator of PKC in hepatocytes [28], were found to inhibit hypoxiainduced EPO mRNA accumulation (Figs. 2, 3). This suppression appeared to be due to a reduction of EPO mRNA synthesis rather than a reduction of mRNA stability (Fig. 7), and it was specific in so far as total RNA synthesis, as determined by uridine incorporation rates, remained almost unaffected (Table 1). The threshold dose of PMA required to reduce EPO mRNA levels was low $\left(10^{-9}-10^{-8} \mathrm{M}\right)$ (Fig. $\left.2 \mathrm{~B}\right)$ and inhibition was apparent already after $1.25 \mathrm{~h}$ of treatment (Fig. $2 \mathrm{C}$ ).

After $2.5 \mathrm{~h}$, the overall abundance of each of five PKC isozymes detected in hepatocytes, as well as their distribution between soluble and particulate fractions, was not affected following incubation with $10^{-8} \mathrm{M}$ PMA (Fig. 4). This provides strong evidence, that the inhibitory effect of phorbol ester on EPO formation was not associated with down-regulation of any of the detectable isozymes of PKC. Moreover, indirect evidence suggests that activation of PKC alpha mediates the PMA-induced inhibition of EPO expression, and that down-regulation of this isozyme antagonizes this inhibition. Thus follow- ing treatment with no less than $10^{-7} \mathrm{M}$ PMA for $2.5 \mathrm{~h}$, a translocation of PKC alpha from cytosol to membranes was observed, indicative of strong activation, and, with increasing doses, a progressive reduction in the overall abundance, presumably reflecting reduced activity. It is conceivable that a combination of these two effects resulted in a maximal inhibition of EPO expression at a dose of $10^{-7} \mathrm{M}$ PMA and that further down-regulation of PKC alpha with further increases in the concentration of PMA is responsible for less efficient inhibition (Fig. 2 B). In addition, the inhibition of hypoxia-induced EPO mRNA levels by PMA was not persistent and was completely reversed after $5-9 \mathrm{~h}$ and after $9-18 \mathrm{~h}$ of treatment with $10^{-6}$ and $10^{-7} \mathrm{M}$ PMA, respectively (Fig. 2 C), and this loss of effect was paralleled by an almost complete down-regulation of PKC alpha after $18 \mathrm{~h}$ (Figs. 4, 5).

Based on the comparison between time- and dosedependent changes in PKC immunoreactivity and inhibition of EPO mRNA accumulation upon exposure to PMA, isozymes other than PKC alpha are less likely to mediate the effect of phorbol ester on EPO formation. In the case of PKC beta II and zeta neither translocation nor down-regulation were observed (Fig. 4). Cytosolic PKC epsilon translocated to membranes, but this isozyme was not down-regulated at any concentration of PMA. PKC delta exhibited a slight down-regulation after $2.5 \mathrm{~h}$ of treatment with $10^{-6} \mathrm{M}$ PMA, but this remained incomplete after $18 \mathrm{~h}$ and, moreover, treatment for $18 \mathrm{~h}$ with $10^{-7} \mathrm{M}$ PMA did neither induce translocation, nor down-regulation of this subtype. In view of the fact that an increasing number of PKC isozymes is 


\section{ค

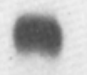

A b c d e f $g$ h std

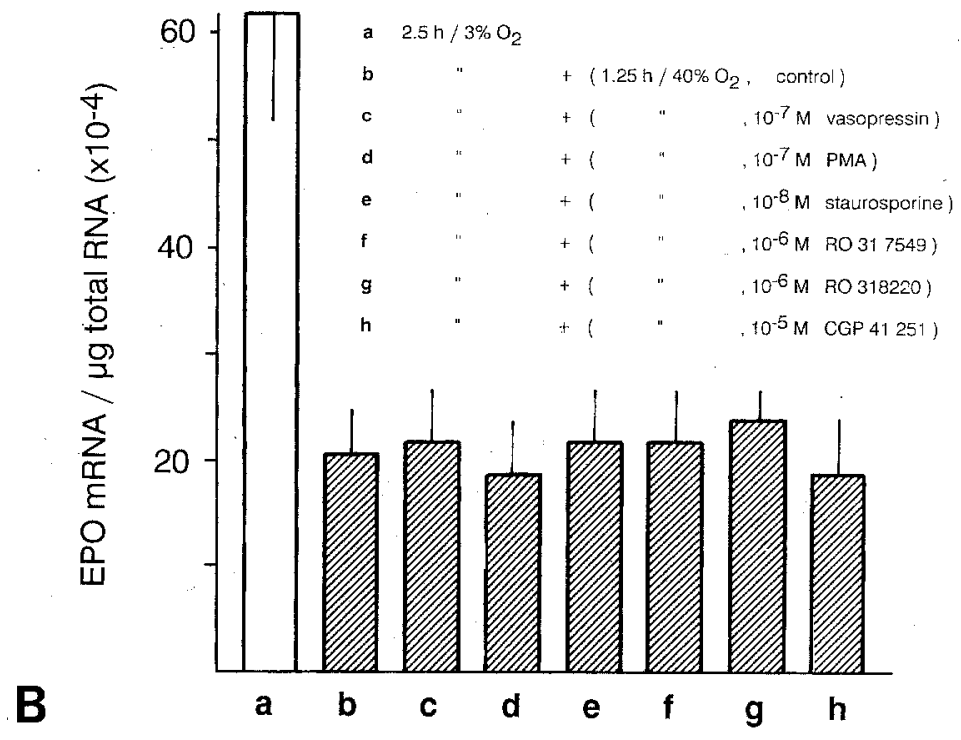

Fig. 7 A, B. Effect of substances found to reduce steadystate levels of EPO mRNA under hypoxic exposure of hepatocytes (see Figs. 2, 3, 6) on the decay of EPO mRNA after hypoxic exposure. Following preincubation at $40 \% \mathrm{O}_{2}$ for $4 \mathrm{~h}$ hepatocytes were first incubated at $3 \% \mathrm{O}_{2}$ for $2.5 \mathrm{~h}$ in the absence of drugs and agents were then added during subsequent incubation at $40 \% \mathrm{O}_{2}$ for $2.5 \mathrm{~h}$ before cells were harvested for isolation of total RNA. A Autoradiograph of an RNAse protection assay of EPO mRNA from cells of a single experiment; $\mathbf{B}$ quantitative analysis of three independent experiments (mean \pm SEM) currently being recognized, we cannot exclude that additional, yet undetected, isozymes may also influence EPO expression. We can also not exclude with certainty that mechanisms other than stimulation and down-regulation of PKC activity contribute to the time- and dosedependent effects of phorbol esters. However, the results obtained so far appear entirely compatible with an inhibitory effect of the activation of PKC alpha on EPO mRNA accumulation in hepatocytes.

A low efficacy of synthetic diacylglyerol analogues in inducing PKC-mediated reactions in hepatocytes has previously been observed $[11,27]$, possibly due to high rates of metabolism of these substances [14]. Thus the failure to lower EPO mRNA levels with DOG or OAG appears no compelling argument against PKC-mediated reduction of EPO gene expression. Following the interpretation that PKC inhibits EPO mRNA accumulation the question arises as to whether basal activity of PKC in hepatocytes may lead to a tonic suppression of EPO formation. Our results suggest, indirectly, that this is not the case. Thus EPO mRNA concentrations after downregulation of $\mathrm{PKC}$ alpha, i. e. after $18 \mathrm{~h}$ of hypoxic exposure (Fig. $2 \mathrm{C}$ ) were only marginally higher than in untreated controls. Moreover, in accordance with this, but in contrast to previous observations in LLCPK 1 cells [42], we did not obtain evidence that hypoxia per se has profound effects on the activity of PKC in hepatocytes; the immunoreactivity of PKC isozymes in soluble and particulate fractions of hepatocytes exposed to $3 \%$ and $40 \%$ oxygen was identical.
A more direct way to study EPO mRNA formation in the absence of PKC activity would be to use inhibitors of this enzyme. In fact seven different agents known to inhibit PKC activity in other systems were found to reduce EPO mRNA expression in isolated hepatocytes (Fig. 6). However, in case of H7, H8 and $\mathrm{H} 9$ the dose/ response curves for inhibition of EPO mRNA accumulation and inhibition of total RNA synthesis were almost identical, indicating that these substances did not specifically interfere with EPO mRNA expression (Fig. 6 C). In contrast, markedly lower concentrations of staurosporine were required for inhibition of EPO mRNA accumulation than for reduction of total RNA synthesis (Fig. 6 A). Also RO 317549 and RO 318220 exhibited some, albeit less, pronounced selectivity for inhibition of EPO mRNA expression as compared to total RNA synthesis (Fig. 6 D), and an incomplete suppression of hypoxia-induced EPO mRNA levels was also found with CGP 41251 (Fig. 6 B).

At first glance this inhibition of EPO mRNA expression with potential inhibitors of PKC seems to contradict the conclusion derived from the experiments with phorbol esters, that PKC is a negative modulator of EPO production. However, none of these inhibitors is specific for PKC, presumably because all are thought to interfere with the catalytic domain of PKC, which shows homology with that of other kinases $[1,40]$. Thus staurosporine is known to inhibit not only PKC but also, for example, cyclic-nucleotide dependent kinases, tyrosine kinase, $\mathrm{Ca}^{2+}$-calmodulin-dependent kinase $[1,40]$ and 
p34 ${ }^{\text {cdc2 }}$-like kinases [20]. The three structurally different derivatives of staurosporine, RO 317549, RO 318220 [9, 12] and CGP 41251 [35] exhibit increased selectivity for PKC, but were also shown previously to inhibit cyclicnucleotide-dependent kinases [9, 26, 35] or tyrosine kinase $[7,35]$. In fact, a comparison of the concentrations of the various inhibitors required to suppress EPO gene induction with those concentrations required to suppress PKC-mediated reactions in other systems suggests that the inhibitory effect on EPO gene expression is not mediated by inhibition of PKC. Thus others have previously reported that staurosporine and RO 318220 are equally potent and that RO 317549 is five- to tenfold less efficient in inhibiting cellular reactions mediated by PKC, such as PMA-induced $\mathrm{P} 47$ phosphorylation in platelets [9] or PMA-induced prostaglandin $\mathrm{E}_{2}\left(\mathrm{PGE}_{2}\right)$ formation in liver macrophages [12]. The concentration of staurosporine that inhibits EPO mRNA expression is in the same range as that required to inhibit PKC-mediated reactions, but both RO 317549 and RO 318220 were 50 -fold less potent than staurosporine in inhibiting EPO mRNA accumulation. Second, CGP 41251 was reported to be 3-9 times less potent than staurosporine in inhibiting the PKC-mediated $\mathrm{H}_{2} \mathrm{O}_{2}$ release from human monocytes, and in inhibiting proliferation of different cell lines [35]. At doses required for these inhibitory effects, CGP 41252 did, however, only marginally affect EPO gene expression, and considering half-maximal inhibition of EPO mRNA accumulation CGP 41252 was approximately 200 -fold less efficient than staurosporine. It appears likely therefore that the effect of these kinase inhibitors is not due to inhibition of PKC, but that another, as yet undefined, kinase activity is an important element in the signal transduction that determines oxygen-dependent control of hepatic EPO mRNA levels. We have previously shown that addition of cAMP and cGMP to hepatocytes incubated at ambient oxygen pressure does not increase EPO mRNA levels, indicating that CAMP- and cGMP-dependent kinases do not directly mediate hypoxic signalling in these cells [16], but this does not exclude a possible permissive role. Moreover, it is important in this respect, that a haem protein was suggested to operate as oxygen sensor in the control of EPO formation [23] and that in Rhizobium meliloti an oxygen-sensing haem protein with kinase activity was identified [21]. Under hypoxic conditions this FixL protein of $R$. meliloti initiates expression of genes required for nitrogen fixation ( $N$ if and fix genes) by protein phosphorylation [36]. It is tempting to speculate that a similar mechanism may be involved in the stimulation of EPO gene transcription.

A comparison of our present results in hepatocytes with previous studies on the role of PKC for EPO production in tumour cells $[25,31,33]$ suggests that the inhibitory effect of both phorbol ester and kinase inhibitors is retained in transformed liver and kidney cells, but significant differences are obvious. First, in contrast to results reported by Jelkmann et al. [31] for Hep G2 cells we did not find that the reduction of EPO formation upon treatment with phorbol esters in hepatocytes is due to depletion of PKC, but rather obtained evidence that the activation of PKC inhibits EPO production. Second, in hepatoma cells EPO production can be fully blunted by phorbol esters $[19,31,33]$, whereas in hepatocytes phorbol esters only attenuated EPO gene expression. Finally, the inhibitory effect of phorbol esters on EPO formation of hepatoma and renal carcinoma cells was found to be long lasting in comparison to the inhibition of EPO formation in hepatocytes. Although in hepatoma cells a direct comparison between EPO mRNA expression and immunoreactivity of PKC isozymes was not performed, one possible explanation which might in part explain the latter two differences is that the time required for downregulation of PKC activity in hepatoma cells is known to be unusually long [13] compared with other cells, including hepatocytes [39]. A prolonged activity of PKC in hepatoma cells would support our interpretation that down-regulation of PKC antagonizes the phorbol ester effect on EPO formation.

In conclusion this study provides evidence that PKC alpha inhibits EPO gene expression in hepatocytes. Although we obtained no evidence that PKC is directly involved in hypoxic signalling, it may be an important negative modulator of EPO formation in vivo. Serum levels of vasopressin, e.g. which is known to induce activation of PKC in hepatocytes [28], were found to increase in hypoxia-exposed rats [46], and it is conceivable that such an increase may partially counteract a rise in EPO mRNA.

Acknowledgements. This work was supported by a grant from the German Research Foundation (DFG, Az Ku 859/5-1). The help of K. H. Götz in preparing the figures is gratefully acknowledged.

\section{References}

1. Azzi A, Boscoboinik D, Hensey C (1992) The protein kinase C family. Eur J Biochem 208:547-557

2. Berry MN, Friend DS (1969) High-yield preparation of iso lated rat liver parenchymal cells: a biochemical and fine structure study. J Cell Biol 43:506-520

3. Beru N, McDonald J, Lacombe C, Goldwasser E (1986) Expression of the erythropoietin gene. Mol Cell Biol 6:25712575

4. Bondurant MC, Koury MJ (1986) Anemia induces accumulation of erythropoietin mRNA in the kidney and liver. Mol Cell Biol 6:2731-2733

5. Borner C, Wyss R, Regazzi R, Eppenberger U, Fabbro D (1987) Immunological quantitation of phospholipid/ $/ \mathrm{Ca}^{2+}-\mathrm{de}-$ pendent protein kinase of human mammary carcinoma cells: inverse relationship to estrogen receptors. Int $\mathbf{J}$ Cancer $40: 344-348$

6. Bradford MM (1976) A rapid and sensitive method for the quantitation of microgram quantities of protein utilizing the principle of protein-dye binding. Anal Biochem 72:248-252

7. Buchdunger E, Regenass U (1992) Differential inhibition of the epidermal growth factor-, platelet-derived growth factor and protein kinase $\mathrm{C}$ mediated signal transduction pathways by the staurosporine-derivative CGP 41251. Cancer Res 52:5353-5358

8. Chomczynski P, Sacchi N (1987) Single-step method of RNA isolation by acid guanidinium thiocyanate-phenol-chloroform extraction. Anal Biochem 162:156-159

9. Davis PD, Hill ChH, Keech E, Lawton G, Nixon JS, Sedgwick AD, Wadsworth J, Westmacott D, Wilkinson SE (1989) Potent 
selective inhibitors of protein kinase C. FEBS Lett 259:6163

10. Dempsey EC, McMurtry IF, O'Brien RF (1991) Protein kinase $\mathrm{C}$ activation allows pulmonary artery smooth muscle cells to proliferate to hypoxia. Am J Physiol 260:L136-L145

11. Diaz-Guerra JM, Boscá L (1990) Lack of translocation of protein kinase $\mathrm{C}$ from cytosol to the membranes in vasopressinstimulated hepatocytes. Biochem J 269:163-168

12. Dieter P, Fitzke E (1991) RO 31-8220 and RO 31-7549 show improved selectivity for protein kinase $\mathrm{C}$ over staurosporine in macrophages. Biochem Biophys Res Commun 181:396401

13. Duronio V, Huber BE, Jacobs S (1990) Partial down-regulation of protein kinase $\mathrm{C}$ reverses the growth inhibitory effect of phorbol esters on Hep G2 cells. J Cell Physiol 145:381389

14. Ebeling JG, Vandenbark GR, Kuhn LJ, Ganong BR, Bell RM, Niedel JE (1985) Diacylglycerols mimic phorbol diester induction of leukemic cell differentiation. Proc Natl Acad Sci USA 82: $815-819$

15. Eckardt K-U, Ratcliffe PJ, Tan CC, Bauer C, Kurtz A (1992) Age dependent expression of the erythropoietin gene in rat liver and kidneys. J Clin Invest 89:753-760

16. Eckardt K-U, Pugh CW, Ratcliffe PJ, Kurtz A (1993) Oxygen dependent modulation of erythropoietin mRNA in rat hepatocytes in vitro. Pflügers Arch 423:356-364

17. Fanburg BL, Massaro DJ, Cerutti PA, Berlin Gail D, Berberich MA (1992) Regulation of gene expression by $\mathrm{O} 2$ tension (conference report). Am J Physiol 262:L235-L241

18. Fandrey J, Bunn HF (1993) In vivo and in vitro regulation of erythropoietin mRNA: measurement by competitive polymerase chain reaction. Blood 81:617-623

19. Faquin WC, Schneider TJ, Goldberg MA (1991) Modulators of protein kinase $\mathrm{C}$ inhibit erythropoietin production in Hep 3B cells (abstract). Clin Res 39:378

20. Gadbois DM, Hamaguchi JR, Swank RA, Bradbury EM (1992) Staurosporine is a potent inhibitor of p34cdc2 and p34cdc2-like kinases. Biochem Biophys Res Commun $184: 80-85$

21. Gilles-Gonzales MA, Ditta GS, Helinski DR (1991) A haemoprotein with kinase activity encoded by the oxygen sensor of Rhizobium meliloti. Nature 350:170-172

22. Goldberg MA, Glass GA, Cunningham JM, Bunn HF (1987) The regulated expression of erythropoietin by two human hepatoma cell lines. Proc Natl Acad Sci USA 84:7972-7976

23. Goldberg MA, Dunning SP, Bunn HF (1988) Regulation of the erythropoietin gene: evidence that the oxygen sensor is a heme protein. Science 242:1412-1415

24. Hagiwara M, Mcnamara DB, Chen I-L, Fisher JW (1984) Role of endogenous prostaglandin E2 in erythropoietin production and dome formation by human renal carcinoma cells in culture. J Clin Invest 74:1252-1261

25. Hagiwara M, Nagakura K, Ueno M, Fisher JW (1987) Inhibitory effects of tetradecanoylphorbol acetate and diacylglycerol on erythropoietin production in human renal carcinoma cell cultures. Exp Cell Res 173:129-136

26. Hidaka H, Inagaki M, Kawamoto S, Sasaki Y (1984) Isoquinolinesulfonamides, novel and potent inhibitors of cyclic nucleotide dependent protein kinase and protein kinase $\mathrm{C}$. Biochemistry 23:5036-5041

27. Hortelano S, Genaro AM, Boscá L (1992) Phorbol esters induce nitric oxide synthase activity in rat hepatocytes. J Biol Chem 267:24 937-24 940

28. Houslay MD (1991) Crosstalk: a pivotal role for protein kinase $C$ in modulating relationships between signal transduction pathways. Eur J Biochem 195:9-27

29. Huwiler A, Schulze-Lohoff E, Fabbro D, Pfeilschifter J (1993) Immunodemonstration of protein kinase isoenzymes in rat kidney glomeruli, and cultured glomerular epithelial and mesangial cells. Exp Nephrol 1:19-25

30. Jelkmann W (1992) Erythropoietin: structure, control of production, and function. Physiol Rev 72:449-489
31. Jelkmann W, Huwiler A, Fandrey J, Pfeilschifter J (1991) Inhibition of erythropoietin production by phorbol ester is associated with down-regulation of protein kinase $\mathrm{C}$-alpha isoenzyme in hepatoma cells. Biochem Biophys Res Commun $179: 1441-1448$

32. Koury ST, Bondurant MC, Koury MJ, Semenza GL (1991) Localization of cells producing erythropoietin in murine liver by in situ hybridization. Blood 77:2497-2503

33. Kurtz A, Eckardt K-U, Pugh CW, Corvol P, Fabbro D, Ratcliffe PJ (1992) Phorbol ester inhibits erythropoietin production in human hepatoma cells (Hep G2). Am J Physiol 262: $\mathrm{C} 1204-\mathrm{C} 1210$

34. Louis J-C, Magal E, Yavin E (1988) Protein kinase C alterations in the fetal brain after global ischemia. J Biol Chem $263: 19282-19285$

35. Meyer T, Regenass U, Fabbro D, Alteri E, Rösel J, Müller M, Caravatiti G, Matter A (1989) A derivative of saturosporine (CGP 41251) shows selectivity for protein kinase C inhibition and in vitro anti-proliferative as well as in vivo anti-tumor activity. Int J Cancer 43:851-856

36. Monson EK, Weinstein M, Ditta GS, Helinski DR (1992) The FixL protein of Rhizobium meliloti can be separated into a heme-binding oxygen-sensing domain and a functional C-terminal kinase domain. Proc Natl Acad Sci USA 89:42804284

37. Nishizuka $Y(1989)$ The family of protein kinase $C$ for signal transduction. JAMA 262:1826-1833

38. Ratcliffe PJ, Jones RW, Phillips RE, Nicholls LG, Bell JI (1990) Oxygen-dependent modulation of erythropoietin mRNA levels. J Exp Med 172:657-660

39. Robles-Flores M, Alcantra-Hernandez R, Garcia-Sainz JA (1991) Differences in phorbol ester-induced decrease of the activity of protein kinase $\mathrm{C}$ isozymes in rat hepatocytes. Biochim Biophys Acta 1094:77-84

40. Rüegg UT, Burgess GM (1989) Staurosporine, K-252 and UCN-01: potent but nonspecific inhibitors of protein kinases. Trends Pharmacol Sci 10:218-220

41. Sahai A, Cole LA, Clarke DL, Tannen RL (1989) Rocking promotes differentiated properties in LLC-PK1 cells by improved oxygenation. Am J Physiol 256:C1064-C1069

42. Sahai A, Guanghui X, Sandler RS, Tannen RL (1992) Hypoxia-mediated impaired differentiation by LLC-PK1 cells: evidence based on the protein kinase $C$ profile. Kidney Int 42:1145-1152

43. Schuster SJ, Wilson JH, Erslev AJ, Caro J (1987) Physiologic regulation and tissue localization of renal erythropoietin messenger RNA. Blood 70:316-318

44. Schuster SJ, Badiavas EV, Costa-Giomi P, Weinmann R, Erslev AJ, Caro J (1989) Stimulation of erythropoietin gene transcription during hypoxia and cobalt exposure. Blood 73:13-16

45. Schuster SJ, Koury ST, Bohrer M, Salceda S, Caro J (1992) Cellular sites of extrarenal and renal erythropoietin production in anemic rats. Br J Haematol 81:153-159

46. Shirakami G, Nakao K, Saito Y, Magaribuchi M, Jougasaki M, Mukoyama M, Arai H, Hosoda K, Suga S, Ogawa Y, Yamada T, Mori K, Imura H (1991) Acute pulmonary alveolar hypoxia increases lung and plasma endothelin-1 levels in conscious rats. Life Sci 48:969-976

47. Shojob M, DeLarco JL, Todaro GJ (1979) Biologically active phorbol esters specifically alter affinity of epidermal growth factor membrane receptors. Nature 279:387-391

48. Stabel S, Parker PJ (1991) Protein kinase C. Pharmacol Ther 51:71-95

49. Tan CC, Eckardt K-U, Firth J, Ratcliffe PJ (1992) Feedback modulation of renal and hepatic erythropoietin messenger RNA in response to graded anemia and hypoxia. Am J Physiol 263:F474-F481

50. Widmer U, Schmid Ch, Zapf J, Froesch ER (1985) Effects of insulin-like growth factors on chick embryo hepatocytes. Acta Endocrinol 108:237-244 